\title{
Japanese Tourism Geography in the 2000s: Researchers, Textbooks and Academic Papers in Japan
}

\author{
ARIMA Takayuki \\ Department of Tourism Science, Tokyo Metropolitan University; Minami-Osawa, Hachiohji, Tokyo, Japan. \\ E-mail: arima@tmu.ac.jp
}

Received February 1, 2013; Accepted June 17, 2013

\begin{abstract}
This article attempts to examine the changes in Japanese tourism geography in the 2000s, clarifying the results of its researchers, textbooks and academic papers, and consider future visions. The most notable development in the changing demographics of the researchers is a drop in the average age. Young researchers who are mainly university students have had the chance to learn tourism geography as a first discipline at their universities. However, judging by the evidence from textbooks, tourism geography in Japan only began to be admitted as an academic discipline in this decade and a statement of definition of tourism geography is going to be more related to 'space' mind rather than 'region' mind. On the other hand, however, none of the textbooks have introduced a common theory or models of tourism space. As regards academic papers in the 2000s, peer-reviewed papers tend to be in major geographical journals in Japan, but a higher number of papers are published in bulletins. This situation may arise from the fact that tourism geography is based mostly on regional studies. Also the methodology of Japanese tourism geography is not as advanced compared with the rest of the world, and more scientific methodology is needed in the research such as statistical method, qualitative survey methods, GIS or collaborative methods with the physical sciences.
\end{abstract}

Key words Japanese, tourism geography, definition, regional studies, methodology

\section{Introduction}

The income from tourism in Japan is regarded as a hope for the rejuvenation of the sagging economy; hence, the government began in the 2000s to subsidize tourism industries, and consequently, the numbers of tourists from overseas have gradually increased. During the past decade, the number has nearly doubled, despite falling in some years because of disasters or accidents. In the same period, tourism studies have become an increasingly popular topic of discussion among Japanese geographers. For instance, the Association of Japanese Geographers (AJG), which is the largest academic group of geographers in Japan, has a study group on tourism and leisure that focuses on various tourism topics. In addition, geoparks have become something of a fad in terms of regional and tourism developments so that physical geographers as well as human geographers have become interested in tourism.

Some researchers have already investigated Japanese research trends in tourism geography, most of them in Japanese (Aoki and Yamamura 1976; Takeuchi 1984; Ishii and Shirasaka 1988; Tsuruta 1994; Yamada 2003; Komatsubara 2003, 2009; Yamato 2009; Kureha 2010). The earliest paper written in English is by Takeuchi
(1984), who had started studying the history of tourism geography in Japan in the 1970s and who also addressed economic and cultural geographical perspectives. Later, Ishii and Shirasaka (1988) identified three subjects for tourism geography studies in Japan: the spatial organization of tourism, landscape formation, and applications to planning. The paper also pointed out future tasks in researching each topic. Ishii and Shirasaka stated that such study areas as urban areas and resorts, and social and cultural perspectives should be further explored. They also pointed out that tourism geography should join in planning, using the realistic and reasonable results of existing research.

Some of these points by Ishii and Shirasaka (1988) remain as tasks to be pursued in the 2000s. Kureha's (2010) review of tourism geography papers in Japan after the 1980s sorted the studies into four themes: regional studies, studies of tourist behaviour, studies of alternative tourism, and studies of international tourism. 'Regional studies', as explicated by Kureha, have much in common with the 'studies of landscape formation' identified by Ishii and Shirasaka. Likewise, Kureha's 'studies of tourist behaviour' may be connected with Ishii and Shirasaka's 'spatial organization of tourism. However, the studies of alternative tourism and international tourism that Kureha 
mentions are new topics in the current tourism situation in Japan. Kureha also noted that distributing the results of such research in English for global consumption was an urgent need.

The characteristics of Japanese tourism geography and the points demonstrated in the above review papers provide us with useful information; however, the situation of Japanese tourism geography has changed dramatically in this decade because of the social conditions mentioned at the beginning of this article. Thus, this article attempts to examine the changes in tourism geography in this decade from the situation of researchers, textbooks and academic papers. It first deals with the changes in researcher demographics in the next chapter. Chapter 3 is an examination of the characteristics of the tourism geography textbooks published in Japan. Textbooks are used mainly by students and researchers for learning about what tourism geography is, so they tend to be excellent repositories for existing concepts of Japanese tourism geography. Chapter 4 deals with academic papers about tourism geography in Japan.

\section{The Researchers of Tourism Geography in Japan}

This chapter analyzes the name lists from the AJG, which is the biggest academic organization for geography in Japan. From these name lists, published every two years, may be determined the number of geographers interested in tourism geography, their ages, their occupations, and their other disciplines of interest.

\section{The changing demographics of tourism geographers}

The lists show every geographer's academic discipline of interest, up to two, although states of the interests of each geographer are not obligatory. This article regards the geographers stating 'tourism geography (kanko chiri)' in the interests as 'tourism geographers.' Figure 1 shows the change in the number of tourism geographers from 2001 to 2011, which larely unchanged in the early 2000s, but gradually increasing after 2007. Although the total number of geographers in the AJG has decreased in this decade, the number of tourism geographers is increasing. Thus, the percent of tourism geographers in the AJG is also increasing, although the rate is still only about $3 \%$. This tendency can be seen not only in the AJG but also in other geographic academic groups in Japan. As a whole, geographers have become relatively more interested in tourism in the 2000s.

The ages of tourism geographers on the lists are shown in Table 1. At the beginning of the 2000s, in 2001 and 2003 , the largest age group of tourism geographers was

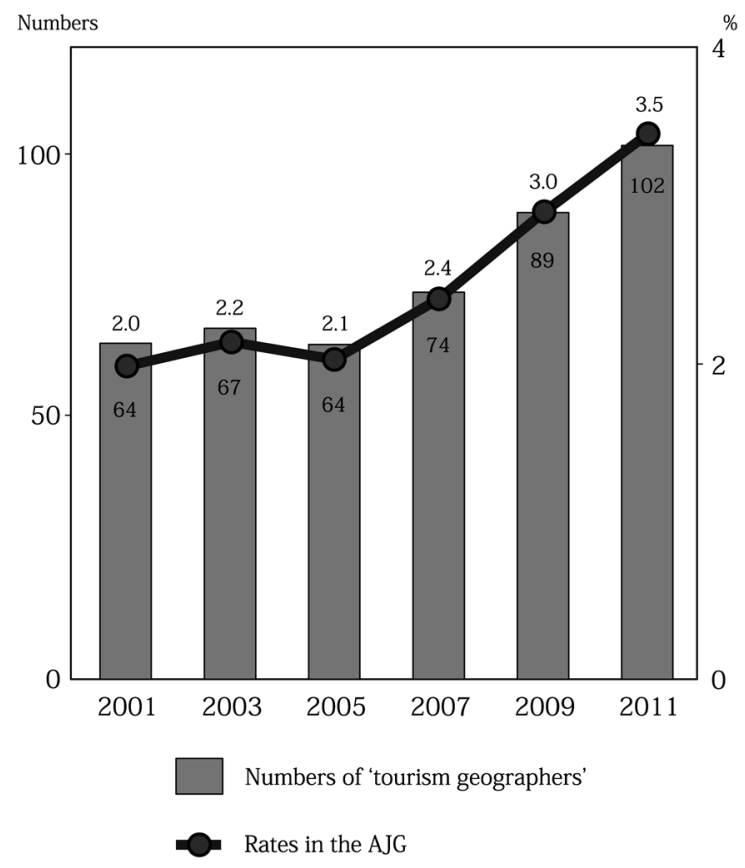

Figure 1. The change in the number of tourism geographers from 2001 to 2011 in the AJG.

Source: the name lists of the AJG.

Table 1. The ages of tourism geographers from 2001 to 2011 in the AJG

\begin{tabular}{|c|c|c|c|c|c|c|}
\hline & 2001 & 2003 & 2005 & 2007 & 2009 & 2011 \\
\hline $20 \mathrm{~s}$ & $11(17.2)$ & $11(16.4)$ & $9(14.1)$ & $13(17.8)$ & $20(22.7)$ & $25(24.8)$ \\
\hline $30 \mathrm{~s}$ & $10(15.6)$ & $16(23.9)$ & $20(31.3)$ & $18(24.7)$ & $23(26.1)$ & $23(22.8)$ \\
\hline $40 \mathrm{~s}$ & $19(29.7)$ & $18(26.9)$ & $15(23.4)$ & $17(23.3)$ & $15(17.0)$ & $17(16.8)$ \\
\hline $50 \mathrm{~s}$ & $10(15.6)$ & $7(10.4)$ & $10(15.6)$ & $13(17.8)$ & $16(18.2)$ & 19 (18.8) \\
\hline $60 \mathrm{~s}$ & $7(10.9)$ & $6(11.9)$ & $4(7.8)$ & $6(6.8)$ & $9(10.2)$ & $10(3.0)$ \\
\hline 70 s and over & $7(10.9)$ & $9(13.4)$ & $6(9.4)$ & $6(8.2)$ & $5(1.1)$ & $7(7.0)$ \\
\hline Total & 64 & 67 & 64 & 73 & 88 & 101 \\
\hline
\end{tabular}

Source: the name lists of the AJG.

( ) represents the rate in each year. Bold represents the largest number in each year. 
Table 2. The occupations of tourism geographers from 2001 to 2011 in the AJG

\begin{tabular}{|c|c|c|c|c|c|c|}
\hline & 2001 & 2003 & 2005 & 2007 & 2009 & 2011 \\
\hline Universities & $26(40.6)$ & $27(40.3)$ & $28(43.8)$ & $35(47.3)$ & $41(46.1)$ & $45(44.1)$ \\
\hline Students & $7(10.9)$ & $11(16.4)$ & $10(15.6)$ & $16(21.6)$ & $21(23.6)$ & $30(29.4)$ \\
\hline Schools & $14(21.9)$ & $13(19.4)$ & $12(18.8)$ & $12(16.2)$ & $13(14.6)$ & $12(11.8)$ \\
\hline Research centres or companies & $10(15.6)$ & $9(13.4)$ & $8(12.5)$ & $7(9.5)$ & $10(11.2)$ & $10(9.8)$ \\
\hline Retired or unknown & $7(10.9)$ & $7(10.5)$ & $6(9.4)$ & $4(5.5)$ & $4(4.5)$ & $5(4.9)$ \\
\hline Total & $64(100)$ & $67(100)$ & $64(100)$ & $74(100)$ & $89(100)$ & $102(100)$ \\
\hline
\end{tabular}

Source: the name lists of the AJG.

( ) represents the rate in each year. Bold represents the largest number in each year.

the 40s. However, the largest age group changed to the 30s in the middle 2000s (in 2005, 2007 and 2009), and by the end of the decade, in 2011, the largest age group in tourism geographers was in their 20s. The average age also decreased during about three years between 2001 and 2011, however this small change does not achieve statistical significance by Mann-Whitney $U$ test. It can appear that part of the reason tourism geographers have been increasing is that the younger generations are more interested in it than previous generations; thus, there is hope that tourism geography will be more highly developed in the future.

The next calculation from the list concerns tourism geographers' occupations. In 2011, 44\% were university professors and 29\% university students. Thus, more than $70 \%$ of tourism geographers were associated with universities in 2011 (Table 2). This percentage of geographers at universities has steadily increased since 2001, especially for students. The number of students increased more than four times, from 7 in 2001 to 30 in 2011. This increase might be related to the change in the age trend, as noted above. On the other hand, the percentage of geographers associated with schools and research centers and companies is decreasing, although the numbers are stable, which means that their interest in tourism is relatively steady. School teachers have opportunities to teach tourism geography to students before they enter university. That gives students a foundation for acquiring further knowledge, so it is needed to increase the ratio of school teachers in tourism geographers.

The most notable development in the changing demographics of Japanese tourism geographers is the trend toward greater numbers of youth-that is related to the fact that Japanese industry, politics, and society have become more interested in the tourism phenomenon, so tourism studies have also increased in popularity as a field of academic study. In fiscal year 2001, there were only 17 courses for tourism studies in universities, but the num- ber had increased to 48 in fiscal year 2010 (Japan Tourism Agency 2010). However this changing situation for tourism studies may lead to further development for tourism geography as an academic discipline in tourism studies. Tourism geography has to have more presence in tourism studies, not only in geographical studies.

\section{The changes related to other disciplines of tourism geographers}

The tourism geographers on the lists can enter other disciplines of their interest. Thus, this study examined the lists in order to understand the related disciplines of tourism geographers in the AJG.

Figure 2 shows the changes in the percentage of related disciplines for tourism geographers. In this category, although almost all of the percentages decreased from 2001 to 2011, 'non related discipline (only tourism geography)' dramatically increased. In 2011, tourism geographers who were not involved in a discipline other than tourism constituted $36 \%$ of all tourism geographers, whereas this rate was only $8 \%$ in 2001 . This may mean that many tourism geographers, especially young geographers in their 20s and 30s, have chosen tourism geography as their single discipline. It must be noted that in the early 2000s, tourism geography could not be regarded as a main discipline for tourism geographers, so they may have chosen others, like agricultural and rural geography and regional development, as their main discipline. Chorography, which is still a major topic in Japanese geography, is the only related discipline that has remained stable, at around $3 \%$. In relation to tourism, some researchers have begun to support regional development with geopark activities, in which they are required to function at the sites as guides or interpreters. Thus, a chorography specialization is useful in this situation, which may explain why these rates have not decreased.

As shown in Figure 2, many rates in related disciplines are decreasing. The percentage for agricultural and rural 


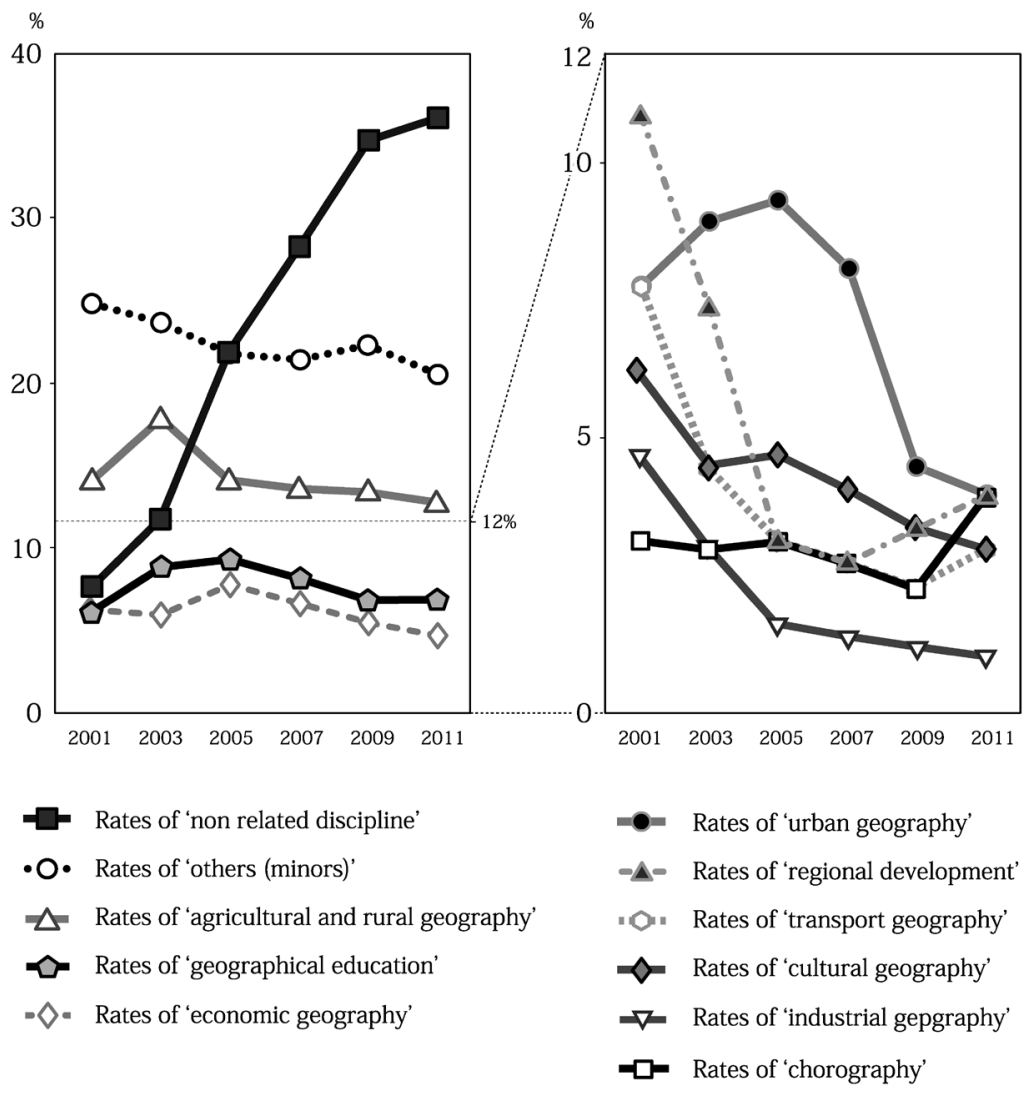

Figure 2. The change in the rate of related disciplines of tourism geographers from 2001 to 2011 in the AJG.

Source: the name lists of the AJG.

geography, especially, decreased over the decade; nonetheless, this field still had the strongest connection to tourism geography in 2011. Tourism geography in Japan started with regional studies, especially at hot springs in rural settings (Yamada 2003). This research history of tourism geography in Japan provides the strongest academic base for it in Japan, so the connection with rural and agricultural geography is still quite strong. The historical connection with Japanese tourism can also be seen in the falling percentages of regional development study and economic geography (Figure 2). These studies were done more during the resort boom period in the 1980s and 1990s. Other disciplines, such as urban transport and industrial geographies, have also experienced a decline.

The decreasing rates in many of the disciplines do not necessarily mean that there is less of a relation between those fields and tourism geography for young researchers because they have had the chance to learn tourism geography as a first discipline at their universities. Tourism geography has gradually come to include other disciplines, such as urban, rural, or industrial geography, as it has developed in the 2000s toward being a discipline in its own right. Tourism geography has now developed into something different for a new generation. Nonetheless, it still includes older geographical concepts like chorogra- phy as it has practical application for regional and societal development.

\section{The Textbooks of Tourism Geography in Japan}

As an increasing number of students study tourism geography, the textbooks have become important for understanding what tourism geography is. This chapter analyzes the contents of the textbooks, which have been collected from online databases: GeNii and Amazon. GeNii is a website containing the best known database of academic books in Japan. The keywords used for the search were 'tourism (kanko)' and 'geography (chirigaku)' in Japanese, and the search was done on 1 November 2012.

\section{General information concerning published textbooks about tourism geography}

Between 3 and 11 books related to tourism geography were published every two years in the 2000s (Figure 3). These books dealing with tourism geography are not limited to textbooks: but the number includes books on general geography, regional study, applied study, and tourism study. In the category of tourism geography textbooks 


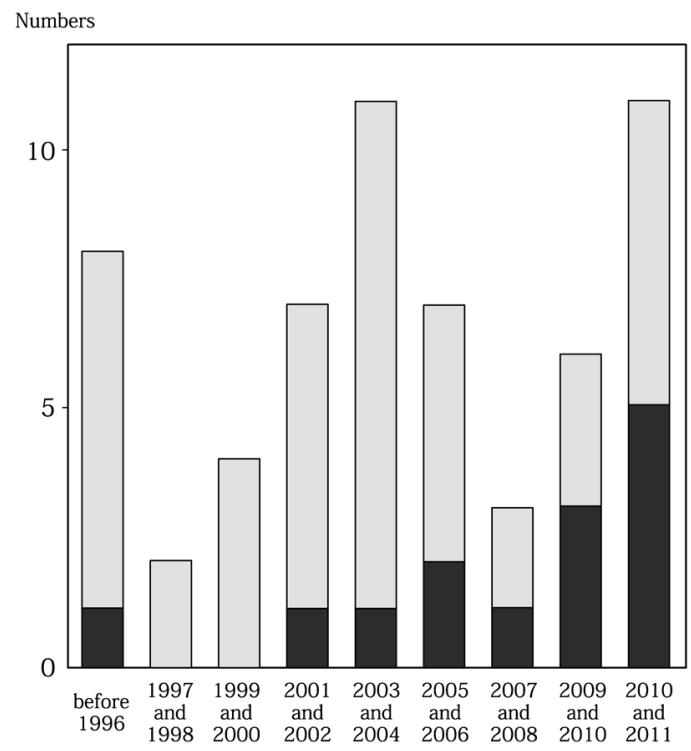

Numbers of published textbooks

Numbers of published other books

Figure 3. The change in the number of academic books on tourism geography in Japan.

Source: data from GeNii and Amazon.

alone, the rate has been increasing since 2001. A total of 12 textbooks were published in the 2000s (Table 3). The increase in tourism geography students at the universities may have stimulated this increase in publishing.

Some tourism geographers who have much experience of tourism geographical research published textbooks both before and during the decade. Junji Yamamura, who published three textbooks after 2001 and two before 2000 (Asaka and Yamamura 1974; Yamamura 1995, 2004, 2010, 2012), is one of the most famous tourism geographers in Japan, having done many regional studies at tourist sites. His textbooks are mostly based on his own and his students' studies, one of whom, Tatsuo Ura, has co-written two tourism geography textbooks (Ura 2006, 2009). His works follow Yamamura's concept of tourism geography, and the concepts presented by the two authors together have shaped tourism geography in Japan. In the late 2000s, especially, other geographers began to publish textbooks: Masaaki Kureha has done many regional studies, especially studies of ski areas, and has summarized studies of tourism geography on the above concepts (Kureha 2011). Kouji Kanda, who specializes in cultural geography, is also introducing studies of tourism geography (Kanda 2011). Akinobu Terasaka, who specializes in urban geography, published a textbook for university students in 2009 (Terasaka 2009). In addition, a Japanese translation of Pearce's (2001) Tourism Today was published in Japan. These many publications demonstrate that the 2000s were the years in which tourism geography was presented in a variety of forms, but the concept of regional studies still slightly dominates tourism geography in Japan.

Textbooks about tourism geography in Japan are divided into three types. The first type is those whose titles include the words 'tourism geography' and which comprise various topics in tourism geography. These are the best known tourism geography textbooks in Japan. Tourism Geography: Issues of Regional Development in Tourist Destinations by Yamamura is the best example in this category. The second type includes those in which tourism geography is introduced in textbooks of general geography; in this type, tourism geography is regarded as a sub discipline of geography in general. For instance, Toward a Practical Geography is an example of this type. The last category is textbooks of tourism studies that introduce tourism geography as a sub discipline of tourism studies, which began to gain serious attention in Japan in the 2000s. Tourism: An Introduction to Jobs and Studies and An Introduction to Tourism Studies are noticeable examples.

In sum, judging by the evidence from textbooks, tourism geography has begun to be admitted as an academic discipline in this decade.

\section{The definitions and themes of tourism geography as found in the textbooks}

Referring to the many books published by tourism geographers, this chapter deals with their definitions of tourism geography. The definition is important if tourism geography is to exist in academia in terms of expressing both its history and its future direction. Most of the textbooks mentioned above have definitions of tourism geography, which will be examined here.

In 2001, Pearce's Tourism Today, the first Japanese translated textbook of tourism geography into Japanese from English by Yoshiaki Naito was published. This book is still the major foreign textbook in Japan and has a greater variety of themes and perspectives on tourism geography than any other Japanese textbooks. The definition of tourism geography in this book is described as 'classifying the connection between origins and destinations' (Table 4). This definition, by emphasising tourist flows as well as regional studies, differs substantially from those in former Japanese textbooks.

Tanno (2005) defined tourism geography as 'revealing tourist flows and distributions of tourist destinations and tourism resources, and also revealing the factors and mechanisms of them' (Table 4). Yamamura, on the 
Table 3. The list of textbooks dealing with tourism geography in Japan

\begin{tabular}{|c|c|c|c|c|c|}
\hline Titles in English & Titles in Japanese & Authors or Editors & $\begin{array}{l}\text { Published } \\
\text { year }\end{array}$ & Publishing company & Volume \\
\hline $\begin{array}{l}\text { Tourism Geography: The } \\
\text { Formations and Issues of } \\
\text { Tourist Areas } 2 \text { nd ed. }{ }^{*}\end{array}$ & $\begin{array}{l}\text { Kankochirigaku: Kankochiiki } \\
\text { no keisei to kadai. Dai } 2 \\
\text { han. }\end{array}$ & Yamamura, J. ed. & 2012 & Dobunkan shuppan & $173 \mathrm{pp}$ \\
\hline $\begin{array}{l}\text { Tourism Geography }{ }^{*} \\
\text { In Recent Tourism Studies' } \\
\text { Commentary }\end{array}$ & $\begin{array}{l}\text { Kankochirigaku } \\
\text { In Gendai kanko komentaru }\end{array}$ & $\begin{array}{l}\text { Komenami, N. } \\
\text { Komenami, N. }\end{array}$ & - & Dobunkan Shuppan & $\begin{array}{r}29 \mathrm{pp} \\
228 \mathrm{pp}\end{array}$ \\
\hline $\begin{array}{l}\text { Aproach from Tourism } \\
\text { geographers } \\
\text { In Toward a practical } \\
\text { geography }\end{array}$ & $\begin{array}{l}\text { Kankochirigaku kara no } \\
\text { apurochi } \\
\text { In Yakunitatsu chirigaku }\end{array}$ & $\begin{array}{l}\text { Yamaguchi, T. } \\
\text { Ito, S., Arima, T., Komaki, N., } \\
\text { Hayashi, T. and Suzuki, K. eds. }\end{array}$ & - & Kokon shoin & $15 \mathrm{pp}$ \\
\hline $\begin{array}{l}\text { Tourism Geography } \\
\text { In Tourism: An introduction } \\
\text { to Jobs and Studies }\end{array}$ & $\begin{array}{l}\text { Kankochirigaku } \\
\text { In Kankogaku nyumon: } \\
\text { Kanko no shigoto, gakushu, } \\
\text { kenkyu wo tsunagu }\end{array}$ & $\begin{array}{l}\text { Kanda, K. } \\
\text { Aoki, Y., Hirooka, Y. and } \\
\text { Kanda, K. eds. }\end{array}$ & - & Shinyosha & $\begin{array}{r}6 p p \\
171 p p\end{array}$ \\
\hline $\begin{array}{l}\text { Studies of Tourism } \\
\text { Geography } \\
\text { In Reference Database of } \\
\text { Tourism Studies in Japan }\end{array}$ & $\begin{array}{l}\text { Kankochirigaku kenkyu } \\
\text { In Kanko kenkyu refarensu } \\
\text { detabesu }\end{array}$ & $\begin{array}{l}\text { Kureha, M. } \\
\text { Eguchi, N. and Fujimaki, M. eds. }\end{array}$ & - & $\frac{-}{\text { Nakanishiya shuppan }}$ & $\begin{array}{l}10 \mathrm{pp} \\
299 \mathrm{pp}\end{array}$ \\
\hline $\begin{array}{l}\text { Tourism Geography: The } \\
\text { Formations and Issues } \\
\text { of Tourist Areas* }\end{array}$ & $\begin{array}{l}\text { Kankochirigaku: Kankochiiki } \\
\text { no keisei to kadai }\end{array}$ & Yamamura, J. ed. & 2010 & Dobunkan shuppan & $165 \mathrm{pp}$ \\
\hline Urban Tourism & $\begin{array}{l}\text { Daigaku tekisuto kanko } \\
\text { chirigaku: Sekai to nihon no } \\
\text { toshi to kanko }\end{array}$ & Terasaka, A. & 2009 & Kokon shoin & $123 \mathrm{pp}$ \\
\hline $\begin{array}{l}\text { An introduction to Tourism } \\
\text { Geography } \\
\text { In An introduction to Tour- } \\
\text { ism Studies 2nd ed. }{ }^{*}\end{array}$ & $\begin{array}{l}\text { Kankochirigaku nyumon } \\
\text { In Zohoban kankogaku } \\
\text { nyumon }\end{array}$ & $\begin{array}{l}\text { Ura, T. } \\
\text { Nakao, K. and Ura, T. eds. }\end{array}$ & - & - & $\begin{aligned} 14 p p \\
215 p p\end{aligned}$ \\
\hline $\begin{array}{l}\text { An introduction to Tourism } \\
\text { Geography } \% \\
\text { In An introduction to } \\
\text { Tourism Studies } \%\end{array}$ & $\begin{array}{l}\text { Kankochirigaku nyumon } \\
\text { In Kankogaku nyumon }\end{array}$ & $\begin{array}{l}\text { Ura, T. } \\
\text { Nakao, K. and Ura, T. eds. }\end{array}$ & - & Koyo shobo & $\begin{array}{r}14 \mathrm{pp} \\
185 \mathrm{pp}\end{array}$ \\
\hline $\begin{array}{l}\text { Trends of Tourism Studies in } \\
\text { Geography } \\
\text { In Tourism as Synthesis } \\
\text { Phenomenon }\end{array}$ & $\begin{array}{l}\text { Chirigaku ni okeru kanko } \\
\text { kenkyu no keifu to hoko } \\
\text { In Sogogensho toshite no } \\
\text { kanko }\end{array}$ & $\begin{array}{l}\text { Tanno, A. } \\
\text { Eguchi, N. ed. }\end{array}$ & - & Koyo shobo & $\begin{aligned} 18 \mathrm{pp} \\
184 \mathrm{pp}\end{aligned}$ \\
\hline $\begin{array}{l}\text { New Tourism Geography } \\
\text { Expanded ed.* }\end{array}$ & $\begin{array}{l}\text { Shin kankochirigaku } \\
\text { (Zouho ban) }\end{array}$ & Yamamura, J. & 2004 & Hara shobo & $284 \mathrm{pp}$ \\
\hline $\begin{array}{l}\text { Tourism Today: } \\
\text { A Geographical Analysis }\end{array}$ & Gendai kankochirigaku & $\begin{array}{l}\text { Pearce, D. (translated by Naito, } \\
\text { Y.) }\end{array}$ & 2001 & Akashi shoten & $524 \mathrm{pp}$ \\
\hline New Tourism Geography & Shin kankochirigaku & Yamamura, J. & 1995 & Taimeido & $270 \mathrm{pp}$ \\
\hline Tourism Geography & Kankochirigaku & Asaka, Y. and Yamamura, J. eds. & 1974 & Taimeido & $234 \mathrm{pp}$ \\
\hline
\end{tabular}

Source: data from GeNii and Amazon.

* represents the English title translated by Arima.

other hand, offered a different definition that respects the Japanese historical tradition in tourism geography. In a new textbook published in 2004, titled New Tourism Geography (which was based on his 1995 text), he introduced tourism geography as an academic discipline that reveals the 'spatial expression of tourism as human activities' (Table 4). This concept is expressed more concretely by Ura's statement, in his textbooks published in 2006 and 2009 , that tourism geography is 'seeing the picture of re- gions or areas through tourism events' (Table 4).

Since the late 2000s, more and varying definitions of tourism geography have been set forth. Terasaka (2009) and Kureha (2011) define it, compared to previous definitions, as more focused on tourists and their behaviour. Although they included tourist behaviour in the definitions, the main perspectives have to do with revealing regions or areas (Table 4). Thus, as Yamaguchi (2012) remarks in his definition, various perspectives of tourism 
Table 4. The definitions of tourism geography in the textbooks in Japan

\begin{tabular}{|c|c|c|c|}
\hline Titles in English & Authors & $\begin{array}{l}\text { Published } \\
\text { year }\end{array}$ & Definitions of tourism geography \\
\hline $\begin{array}{l}\text { Tourism Geography: The Formations and } \\
\text { Issues of Tourist Areas } 2 \text { nd ed. }\end{array}$ & Yamamura, J. & 2012 & $\begin{array}{l}\text { revealing various aspects of nature, history, society } \\
\text { and culture in tourism region in a comprehensive } \\
\text { and a dynamic (p 17) }\end{array}$ \\
\hline $\begin{array}{l}\text { Tourism Geography In Recent Tourism } \\
\text { Studies' Commentary }\end{array}$ & Komenami, N. & 2012 & - \\
\hline $\begin{array}{l}\text { Aproach from Tourism geographers in } \\
\text { Toward a practical geography }\end{array}$ & Yamaguchi, T. & 2012 & $\begin{array}{l}\text { grasping tourism areas by various perspectives } \\
\text { (p 53) }\end{array}$ \\
\hline $\begin{array}{l}\text { Tourism Geography In Tourism: An } \\
\text { introduction to Jobs and Studies }\end{array}$ & Kanda, K. & 2011 & $\begin{array}{l}\text { revealing the characteristics of tourism space and } \\
\text { understanding what tourism is ( } \mathrm{p} 118)\end{array}$ \\
\hline $\begin{array}{l}\text { Studies of Tourism Geography In Reference } \\
\text { Database of Tourism Studies in Japan }\end{array}$ & Kureha, M. & 2011 & $\begin{array}{l}\text { revealing the characteristics of tourist behaviours } \\
\text { and regional aspects brought by them ( } p 11)\end{array}$ \\
\hline $\begin{array}{l}\text { Tourism Geography: The Formations and } \\
\text { Issues of Tourist Areas }\end{array}$ & Yamamura, J. & 2010 & $\begin{array}{l}\text { revealing various aspects of nature, history, society } \\
\text { and culture in tourism region in a comprehensive } \\
\text { and a dynamic ( } p 17)\end{array}$ \\
\hline Urban Tourism & Terasaka, A. & 2009 & $\begin{array}{l}\text { understanding connections between tourist } \\
\text { behaviours and regions ( } \mathrm{p} 2)\end{array}$ \\
\hline $\begin{array}{l}\text { An introduction to Tourism Geography In } \\
\text { An intorduction to Tourism Studies 2nd } \\
\text { ed. }\end{array}$ & Ura, T. & 2009 & $\begin{array}{l}\text { seeing the picture of regions or areas through } \\
\text { tourism events ( } p 143 \text { ) }\end{array}$ \\
\hline $\begin{array}{l}\text { An introduction to Tourism Geography In } \\
\text { An intorduction to Tourism Studies }\end{array}$ & Ura, T. & 2006 & $\begin{array}{l}\text { seeing the picture of regions or areas through tour- } \\
\text { ism events ( } p 141)\end{array}$ \\
\hline $\begin{array}{l}\text { Trends of Tourism Studies in Geography In } \\
\text { Tourism as Synthesis Phenomenon }\end{array}$ & Tanno, A. & 2005 & $\begin{array}{l}\text { revealing tourist flows and distributions of tourist } \\
\text { destinations and tourism resources, and also } \\
\text { revealing the factors and mechanisms of them } \\
\text { (p15) }\end{array}$ \\
\hline New Tourism Geography Expanded ed. & Yamamura, J. & 2004 & $\begin{array}{l}\text { revealing spatial expression of tourism as human } \\
\text { activities ( } \mathrm{p} 15)\end{array}$ \\
\hline Tourism Today: A Geographical Analysis & Pearce, D. (translated by Naito, Y.) & 2001 & $\begin{array}{l}\text { classifying the connection between origins and } \\
\text { destinations ( } \mathrm{p} 24)\end{array}$ \\
\hline New Tourism Geography & Yamamura, J. & 1995 & $\begin{array}{l}\text { revealing spatial expression of tourism as human } \\
\text { activities ( } p 15)\end{array}$ \\
\hline Tourism Geography & Asaka, Y. and Yamamura, J. & 1974 & $\begin{array}{l}\text { grasping tourism area through the formations, } \\
\text { fuctions and mechanizms of tourism industries } \\
\text { and tourism settlement ( } p 16)\end{array}$ \\
\hline
\end{tabular}

Source: each textbook.

geography are still admitted. However, as Kanda (2011) notes, the most important concept in the definition of Japanese tourism geography has to do with revealing the characteristics of tourism space, including tourist destinations and regions (Table 4). The truth of this statement is borne out by the fact that all the definitions in the textbooks of tourism geography in Japan are indexed under the keywords tourism and region or space. So, exploring the definition history reveals that the research objects of tourism geography in Japan became broader from analyzing 'region' to 'space' in the 2000s, and this is indicated in the textbooks.

Tourism geography in Japan has several perspectives; the most common and traditional ones, as described in the textbooks, look at the development history of tourist destinations. This is the focus in the textbooks of Yama- mura $(1995,2004,2010,2012)$ and Tanno (2005). Another perspective describes many aspects of similar tourist destinations, such as urban areas and rural areas, for comparison purposes. Terasaka (2009) deals with many urban areas in the world in his textbook. Investigating tourist behaviour or areas according to cultural perspectives is also introduced but not in a detailed way in any of the textbooks. None of the textbooks have introduced a common theory or models for tourism geography in the world except for the Japanese translation of Pearce's (2001) book. This situation is a problem for students in universities who want to learn the theories and models of tourism geography as a science.

In general, the most stable definition of tourism geography in Japan now can be offered as 'revealing the characteristics of tourism space-including tourist 
destinations, regions, and areas-by various approaches including regional livelihoods and developments and tourist flows and behaviour, and so on.' It is not a drawback that its perspectives are various, but base theories and models are greatly needed in Japan.

\section{Academic Papers of Tourism Geography in Japan}

So far, this paper has established that Japanese tourism geography is an academic discipline dealing with tourism space in various ways. Is this situation detectable in the academic literature from the 2000s? This chapter discusses the front-line research on tourism geography in Japan. First, the number of the papers each year from 2001 to 2010 was counted. The count is derived from the CiNii database, which is the most famous Web database of academic papers in Japan. Two keywords were used in the search: 'tourism (kanko)' and 'geography (chirigaku)' in Japanese. According to the results of the search, 179 papers, each of them over four pages in length, were published from 2001 to 2010.

\section{Outlines of the academic papers}

In each year of the first half of the 2000s, about 10 to 20 papers on tourism geography were published (Figure 4 ). During the last half of the decade, and especially after 2008, more than 20 papers per year were published. This changing trend is similar to changes in the numbers of tourism geographers and textbooks; thus, the trends already perceived in tourism geography are reflected in the academic literature.

The bulletins of universities published $54 \%$ of the academic papers (Figure 5). The top three bulletins, which have many of the articles, are The International Journal of Tourism Science from Tokyo Metropolitan University, the Annals of Human and Regional Geography from the University of Tsukuba, and Tsukuba Studies in Human Geography, also published by the University of Tsukuba (Table 5). These three bulletins account for 33\% of all the bulletin literature. These universities have a long history of geographical research, staff, and students; thus, they serve to support research into many tourism destinations and offer a great deal of teaching experience in geography.

The second largest category of papers consists of those published by academic societies, constituting $40 \%$ of all papers (Figure 5). Most of these papers are peer-reviewed, so they would be the most reliable papers on tourism geography in Japan, as there are no academic journals that simply target only tourism geography. However, the top

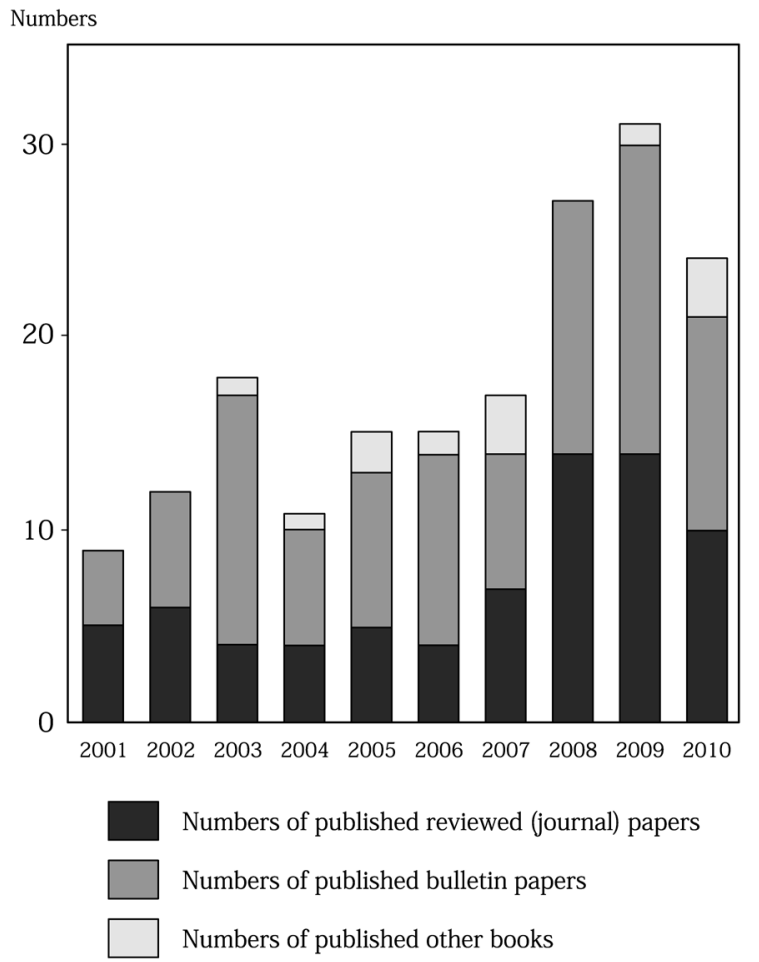

Figure 4. The change in the number of academic papers on tourism geography from 2001 to 2010 in Japan.

Source: data from CiNii.

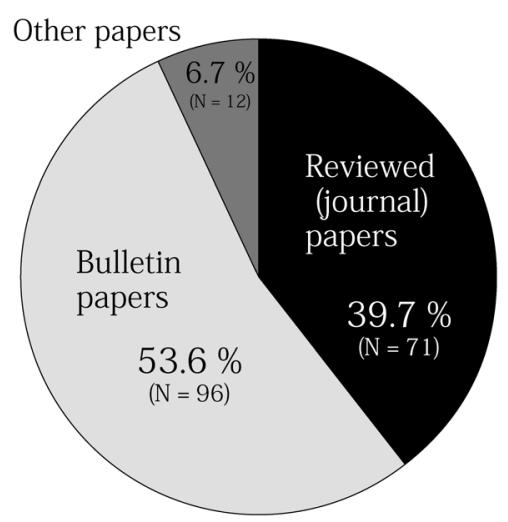

Figure 5. The rate of types of academic papers on tourism geography in 2001 to 2010 in Japan. Source: data from CiNii. $\mathrm{N}=179$

three journals in which these papers are published, Geographical Sciences, Japanese Journal of Human Geography, and Geographical Review of Japan, are the major human geographical journals in Japan (Table 5). Half of all the peer-reviewed tourism geography papers in the 2000s are in these three journals, demonstrating that tourism geography in Japan is appealing mainly to those interested in human geography as an academic discipline.

The rest of the academic papers were published in proceedings and reports. There are not very many because papers of under four pages were excluded from the count. 
Table 5. The top 12 of journals, bulletins and other papers, which have many of the papers of tourism geography from 2001 to 2010 in Japan

\begin{tabular}{|c|c|c|c|c|c|}
\hline Titles of journals, bulletins or prodeedings & Types & Publishers & $\begin{array}{l}\text { Numbers of } \\
\text { papers }\end{array}$ & Rates & $\begin{array}{l}\text { Cumulative } \\
\text { rates }\end{array}$ \\
\hline The International Journal of Tourism Science & B & Tokyo Metropolitan University & 17 & $9.5 \%$ & $9.5 \%$ \\
\hline Geographical Sciences & $J$ & $\begin{array}{l}\text { The Japanese Society for Geographical Sci- } \\
\text { ences }\end{array}$ & 15 & $8.4 \%$ & $17.9 \%$ \\
\hline Japanese Journal of Human Geography & J & The Human Geographical Society of Japan & 13 & $7.3 \%$ & $25.1 \%$ \\
\hline Geographical Review of Japan & J & The Association of Japanese Geographers & 9 & $5.0 \%$ & $30.2 \%$ \\
\hline Annals of Human and Regional Geography & $\mathrm{B}$ & University of Tsukuba & 8 & $4.5 \%$ & $34.6 \%$ \\
\hline Tsukuba Studies in Human Geography & B & University of Tsukuba & 7 & $3.9 \%$ & $38.5 \%$ \\
\hline The New Geography & J & The Geographic Education Society of Japan & 5 & $2.8 \%$ & $41.3 \%$ \\
\hline $\begin{array}{l}\text { Bulletin of Ohkagakuen University Faculty of } \\
\text { Humanities }\end{array}$ & B & Ohkagakuen University & 4 & $2.2 \%$ & $43.6 \%$ \\
\hline Geography Review of Akita University & J & Akita University & 4 & $2.2 \%$ & $45.8 \%$ \\
\hline Regional Study & $J$ & Rissho University & 4 & $2.2 \%$ & $48.0 \%$ \\
\hline Annals of the Geography & J & Nihon University & 4 & $2.2 \%$ & $50.3 \%$ \\
\hline $\begin{array}{l}\text { Papers and Proceedings of the Geographic } \\
\text { Information Systems Association }\end{array}$ & $\mathrm{O}$ & GIS Association of Japan & 4 & $2.2 \%$ & $52.5 \%$ \\
\hline
\end{tabular}

Source: data from CiNii.

$N=179$

Types: 'B' represents bulletins (bulletins papers). 'J' represents academic journals (reviewed papers). 'O' represents other academic papers (other papers).

However, some of these papers represent the new face of tourism geography. Papers and Proceedings of the Geographic Information Systems Association, published by the GIS Association of Japan, has four papers related to tourism geography. Some tourism geographical studies have used GIS techniques as tools for research or applications, and this trend may improve with the development of general geography using GIS.

It has been demonstrated so far that papers related to tourism geography are published in bulletins as well as in journals. Peer-reviewed papers tend to be in major geographical journals, but a higher number of papers are published in bulletins. This situation may arise from the fact that tourism geography is based mostly on regional studies. It is difficult to review regional studies and certify them in a scientific way, which is the academic approach. Thus, other approaches may be needed for increasing reviewed papers in journals, and using GIS techniques may be an option for doing that.

\section{The data and methodology of reviewed papers}

Kureha (2010) has described in detail the content of tourism geography papers; hence, it will not be treated deeply here. Rather, shown here are such general matters as the authors, types, data, and methods of 71 peerreviewed papers from 2001 to 2010. Figure 6 shows the percentages of first authors' occupations. $61 \%$ of the au-

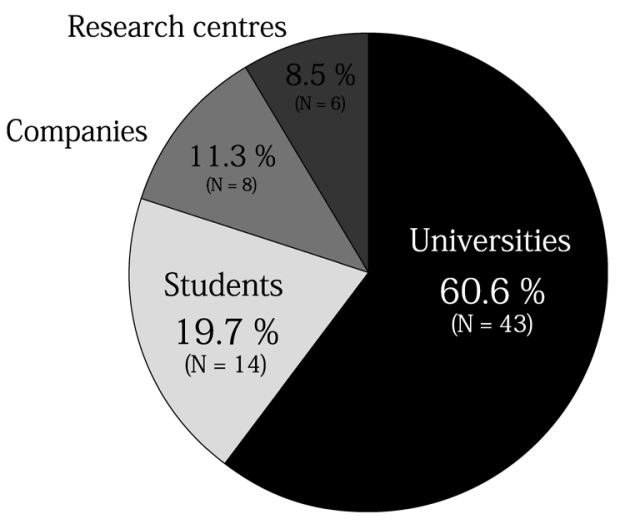

Figure 6. The rate of first authors' occupations of reviewed papers on tourism geography in 2001 to 2010 in Japan.

Source: each paper. $\mathrm{N}=71$

thors belong to a university (Figure 6). This percentage is different from that of the members of the AJG (Table 2) and shows that tourism geography research is done mainly by researchers in universities. The research is also done by researchers in companies and research centres because of the characteristics of tourism studies itself. The result of tourism studies including tourism geography can contribute to regional or business development so that the research tends to be supported by not only universities but also private companies or research centres.

As Kureha (2010) pointed out, tourism geography re- 
Education oriented

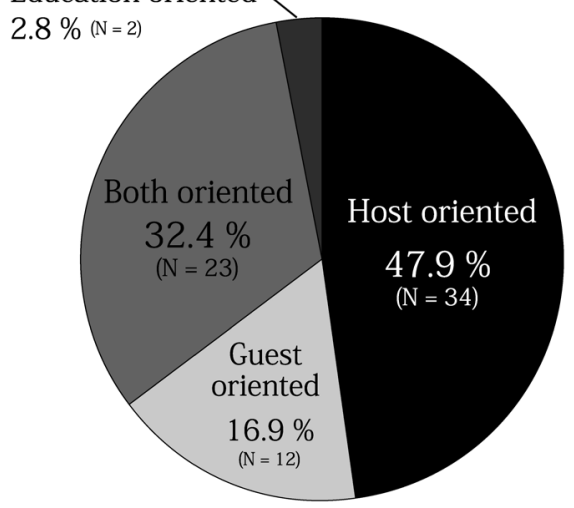

Figure 7. The rate of oriented types of reviewed papers on tourism geography in 2001 to 2010 in Japan.

Source: each paper. $N=71$

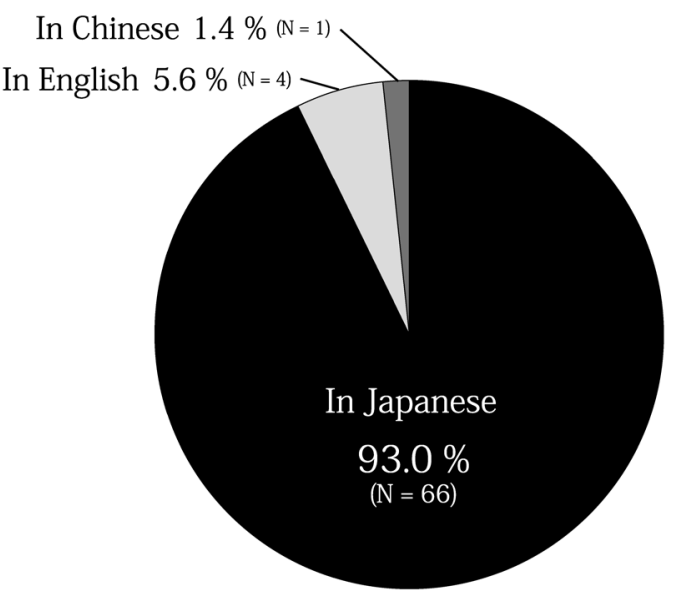

Figure 8. The rate of written languages of reviewed papers on tourism geography in 2001 to 2010 in Japan.

Source: each paper. $N=71$

search is biased toward regional studies. For checking this bias statistically, the papers are divided into four types according to the contents of each paper: host, guest, both, and educational oriented types. The host-oriented research refers to papers that aim at understanding landscapes and locals' lives at study sites. The guest-oriented research deals mainly with tourists and their behaviour. Papers of both orientations mean that the papers are equally divided between the locals and the tourists. Almost half of the papers are of the host-oriented research (Figure 7). This characteristic probably arises from the history of Japanese tourism geography. Also, this result might be related to low concern for studies done abroad, and the low percentage of English papers (6\%; see Figure 8 ) would lead to the same conclusion. Although regional studies offer important perspectives, the comparative perspective with other studies, such as guest-oriented

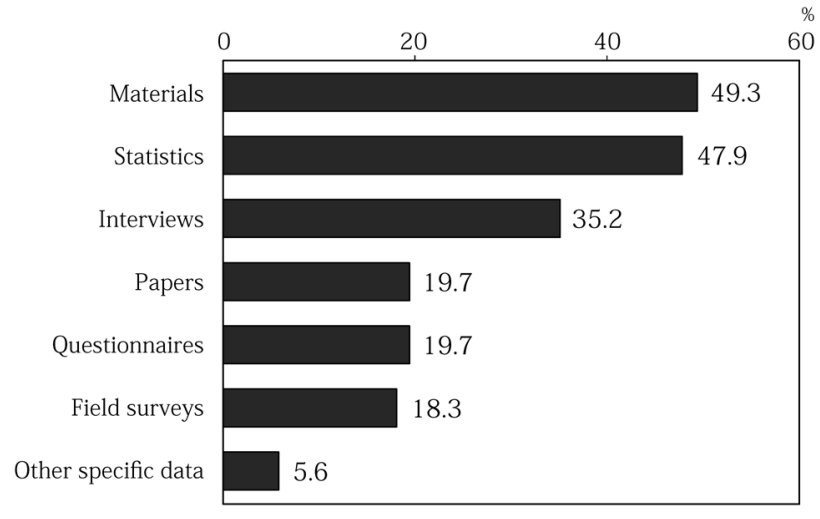

Figure 9. The rate of data collection methods in reviewed papers on tourism geography in 2001 to 2011 in Japan.

Source: each paper. $N=71$

research, for creating theories is much more important if tourism geography is ever to achieve the status of a science.

For a science, data collection and methodology is also important because of verifying accuracy and repeatability. Figure 9 shows the percentage of data collection methods in the papers. Most of the data collection came from materials. The materials are leaflets, brochures, or local government materials that are used for looking at local cultures and physical conditions in the study areas. These are used for both host and guest-oriented studies. Statistics are used mainly in the early chapters of the papers for introducing the general characteristics of a study area, but not much for analysing objects. The interviews are data gleaned through personal interviews with locals, government offices, or companies. This data collection method can be seen mainly in the host-oriented paper category. Regional studies tend to research changes in regions according to physical and social dimensions. From interviews, quality data can be collected concerning the social dimension that cannot be obtained from physical and statistical data. The uniqueness of Japanese tourism geography may also be seen in that not very much of data are gathered through questionnaire surveys (Figure 9). The surveys used are mainly tourist surveys relating to the guest-oriented research. This type of research is not as common in Japan, especially in Japanese geography. Other specific data are quite inferior, so more work needs to be done in this respect.

The methodology of tourism geography in Japan is not always advanced compared with that in the rest of the world. Fifty-six percent of the papers draw maps by means of data collection, and read them. This methodology, which is the most common and specialized method 


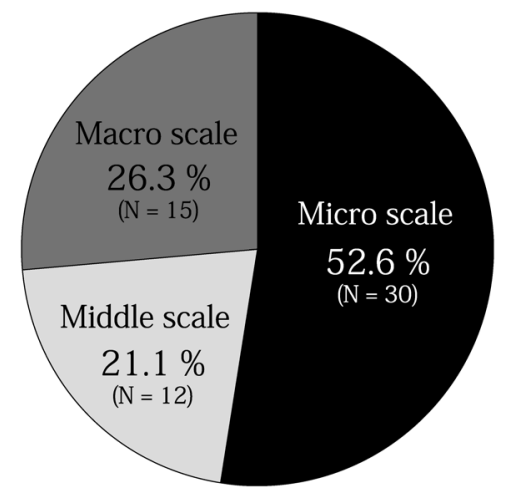

Figure 10. The rate of the scales of study area in the papers on tourism geography in 2001 to 2010 in Japan.

Source: each paper (not included 14 review papers). $\mathrm{N}=57$

Micro scale is from site to village scale. Middle scale is several villages or cities scale. Macro scale is from whole prefecture to national scale.

in geography, can be seen in only about half of the papers. Other specific methodologies cannot be found except for descriptions of statistics and materials. More specifically, statistical tools, such as tests or multiple techniques, are seen in only $11 \%$ of the papers. Compared to other related disciplines-such as GIS, climatology, and ecological research-this percentage is very low. Hence, more use of statistical methodology is needed in research in order to understanding the data, but there is not much reliable statistical data about tourism compared with other social statistical data in Japan.

Because geography essentially deals with spaces, the scale of research objects can be an important topic. Half of the papers were done on a micro scale, like investigations of sites and villages at the research targets (Figure 10). This type of research is also influenced by the data collection and methodologies mentioned above. Most of the data collection methods used in the research were restricted by the scale of the research. For instance, field surveys are more usable on a micro scale for researchers on foot, such as researching in a village, rather than on a wider scale, such as in a wider region or a nation. This trend is also reflected more in host-oriented research projects, whereas research on a macro scale tends to be for understanding tourist flows or cultural perspectives. Additionally, the regions where research has been done are also counted. The quantity is not high for each region, but Table 6 shows that the Kinki, Kyushu, Kanto and Tohoku regions represent higher percentages compared with the number of prefectures; however, the percentage of researches in the Chugoku region is low. In addition, the number of papers on destinations abroad constitutes
Table 6. The regions of study areas in the papers on tourism geography in 2001 to 2011 in Japan

\begin{tabular}{|l|c|c|}
\hline \multicolumn{1}{|c|}{ Study areas } & Numbers & $\begin{array}{c}\text { Rate in numbers of } \\
\text { prefectures in each } \\
\text { region }\end{array}$ \\
\hline Hokkaido & $2(2.8)$ & 2.00 \\
\hline Tohoku & $5(7.0)$ & 0.83 \\
\hline Kanto & $6(8.5)$ & 0.86 \\
\hline Chubu & $6(8.5)$ & 0.67 \\
\hline Kinki & $7(9.9)$ & 1.00 \\
\hline Chugoku & $2(2.8)$ & 0.40 \\
\hline Shikoku & $3(4.2)$ & 0.75 \\
\hline Kyushu & $7(9.9)$ & - \\
\hline Japan & $10(14.1)$ & - \\
\hline Foreign & $18(25.4)$ & - \\
\hline No region & $5(7.0)$ & - \\
\hline Total & $71(100)$ & - \\
\hline Sources & & - \\
\hline
\end{tabular}

Source: each paper.

( ) represents the rate in all reviewed papers.

about $25 \%$ of all papers. In summary, research in tourism geography is still biased on host-oriented research, which is derived from being based on regional studies. This situation leads to many studies on the micro scale, written in Japanese, and not using statistical tools. Therefore, more studies using various data and methods, and from different perspectives and study areas are needed in Japan.

\section{Conclusion}

This paper portrays tourism geography in Japan in the 2000s by looking at researchers, textbooks, and academic papers. The researcher trends show that the average researcher age is becoming slightly younger as young people are beginning to pursue studies in tourism geography. Tourism geography also has a strong relationship with other human geographical phenomena. Because tourism is not the only economic activity even in the tourism field, students need to have a variety of knowledge and understand other activities. They should also understand what tourism is and that tourism spaces are in their study areas.

The characteristics of Japanese tourism geography are largely reflected in the textbooks. Many textbooks consist of a collection of several regional studies. Such a bias of the contents may lead students to conduct more regional studies, but varying perspectives, data, and methods are needed or textbooks will not differ from those in the 
past. However some textbooks are trying to define tourism geography in broader meanings from 'region' mind to 'space' mind. For the proper education of students in the university, new concepts are needed in the textbooks. Also theories and models of tourism geography are important for the contents of textbooks, although Japanese tourism geography, unfortunately, has not developed common theories and models, and also has not introduced them in the textbooks. These may need to be gathered from abroad as textbooks are lacking innovative concepts and theories.

Researchers are the most important element in theorizing and creating models for textbooks. Many researchers are still concentrating on regional studies, and, whereas this is not an exceptional theme in geography, theories and models still need to be created from such studies. Japanese tourism geographers have been trying to understand 'tourism spaces' by many regional studies so that the researchers have a commitment to create such theoretical models from the results. Older researchers have much more experience for doing this, and it would be helpful for the development of tourism geography. So, more communication between older and younger researchers and between researchers from abroad and Japanese researchers is needed.

In addition to that, tourism is connected to various phenomena not only among humans but also in nature. Thus, tourism geography can be associated with the physical sciences, such as climatology and geology. For example, how does global warming affect tourism activities, spaces, or mobilities, and how do tourism phenomena react to natural disasters? These are good examples of possible collaborative activities with the physical sciences, but there are no such collaborative studies in Japan. In terms of collaborations, understanding space is the keyword for each discipline with regard to geography. In this situation, GIS techniques can help our understanding in a scientific way; thus, GIS studies are also becoming more important to tourism geography.

\section{References}

Aoki, E. and Yamamura, J. 1976. Perspective on recreational geography in Japan, 1924-1975: A bibliographical study. Japanese Journal of Human Geography 28: 171-194. (JE)

Asaka, Y. and Yamamura, J. eds. 1974. Tourism Geography. Tokyo: Taimeido. (J)

Ishii, H. and Shirasaka, S. 1988. Recent studies on recreational geography in Japan. Geographical Review of Japan 61B: 635-659.
Japan Tourism Agency (JTA) 2010. The policy of industryAcademia-Government collaboration for development human resource for Japanese tourism. http://www.mlit.go.jp/ common/000119660.pdf (last accessed 15 April 2013)

Kanda, K. 2011. Tourism geography. In Tourism: An introduction to jobs and studies, ed. Y. Aoki, Y. Hirooka and K. Kanda, 118-123. Tokyo: Shinyosha. (J)

Komatsubara, H. 2003. A research about studies of tourist geography and traffic geography. Nara Prefectural University Kenkyu Kiho 13: 13-17. (J)

Komatsubara, H. 2009. Tourism in research on the structure of human mobility flows. Geographical Sciences (Chiri Kagaku) 64: 140-150. (JE)

Kureha, M. 2010. Research trends in the geography of tourism in Japan. Japanese Journal of Human Geography 62: 558-569. (JE)

Kureha, M. 2011. Studies of tourism geography. In Reference database of tourism studies in Japan, ed. N. Eguchi and M. Fujimaki, 11-20. Kyoto: Nakanishiya Shuppan. (J)

Pearce, D. 2001. Tourism today: A geographical analysis second edition. Harlow: Longman Group Limited. Translated by Naito, Y. 2001. Gendai kankochirigaku. Tokyo: Akashi Shoten. (J)

Tanno, A. 2005. Trends of tourism studies in geography. In Tourism as Integrated Phenomenon, ed. N. Eguchi, 1-18. Kyoto: Koyo Shobo. (J)

Takeuchi, K. 1984. Some remarks on the geography of tourism in Japan. GeoJournal 9: 85-90.

Terasaka, A. 2009. Urban Tourism. Tokyo: Kokon Shoin. (J)

Tsuruta, E. 1994. Current trends in Japanese tourism geography and the post-resort boom era: Towards a sublation between Anglo-American and Japanese studies. Japanese Journal of Human Geography 46: 66-84. (J)

Ura, T. 2006. An introduction to tourism geography. In An introduction to tourism studies. ed. K. Nakao and T. Ura, 137-150. Kyoto: Koyo Shobo. (J)

Ura, T. 2009. An introduction to tourism geography. In An introduction to tourism studies 2 nd ed. ed. K. Nakao and T. Ura, 137-150. Kyoto: Koyo Shobo. (J)

Yamada, K. 2003. Trends in tourism research on geography of mountainous areas. Rikkyo University Bulletin of Studies in Tourism 5: 138-143. (J)

Yamaguchi, T. 2012. Approach from tourism geographers. In Toward a practical geography. ed. S. Ito, T. Arima, N. Komaki, T. Hayashi and K. Suzuki, 51-64. Tokyo: Kokon Shoin. (J)

Yamamura, J. 1995. New tourism geography. Tokyo: Taimeido. (J)

Yamamura, J. 2004. New tourism geography. Expanded ed. Tokyo: Hara Shobo. (J)

Yamamura, J. ed. 2010. Tourism geography: The formations and issues of tourist areas. Tokyo: Dobunkan Shuppan. (J)

Yamamura, J. ed. 2012. Tourism geography: The formations and issues of tourist areas 2nd ed. Tokyo: Dobunkan Shuppan. (J)

Yamato, K. 2009. Result and review of tourism and recreation studies. Annals of the Geography 50: 17-22. (J)

(J) written in Japanese

(JE) written in Japanese with English abstract 